\title{
Morphology and Molecular Phylogeny of Fusarium solani Isolated from Kuruma Prawn Penaeus japonicus with Black Gills
}

\author{
Le Van Khoa ${ }^{1,2}$, Kishio Hatai ${ }^{1 *}$, Akihiko Yuasa ${ }^{3}$ and Kenzo Sawada ${ }^{3}$ \\ ${ }^{1}$ Division of Fish Diseases, Nippon Veterinary and Animal Science University \\ Musashino, Tokyo 180-8602, Japan \\ ${ }^{2}$ Research Institute for Aquaculture No.1, Bac Ninh city, Hanoi, Vietnam \\ ${ }^{3}$ Fisheries Research Institute, Tokushima Agriculture, Forestry and \\ Fisheries Technology Support Center, Tokushima 779-2304, Japan
}

(Received May 13, 2005)

\begin{abstract}
Nine strains of fungi in the genus Fusarium were isolated from the lesions with black gills of cultured kuruma prawn Penaeus japonicus in Japan between 2000 and 2003 . All strains showed same morphological characters. Two strains selected at random showed pathogenicity to kuruma prawns by intramuscular injection. From the precise morphological features of a representative isolate, it was identified as a member of the Fusarium solani complex. Phylogenetic analyses based on the sequences of its internal transcribed spacer region, including 5.8S ribosomal DNA and a partial $28 \mathrm{~S}$ ribosomal DNA region, showed that all five strains tested were monophyletic. The present strains and the phytopathogenic Fusarium solani were clearly distinguished by the morphological and phylogenetical characteristics.
\end{abstract}

Key words: Fusarium solani, molecular phylogeny, Penaeus japonicus, black gill, morphology

Some species in the genus Fusarium such as Fusarium solani (Egusa and Ueda, 1972), F. moniliforme (Rhoobunjongde et al., 1991) and $F$. oxysporum (Hassan et al., 1999) have been isolated from kuruma prawns Penaeus japonicus with black gills. Among these species, $F$. solani has subsequently been reported as an important pathogen. F. solani has also been isolated from American lobsters Homarus americanus (Lightner and Fontain, 1975), brown shrimp Penaeus californiensis (Hose et al., 1984), bonnethead sharks Sphyrna tiburo (Muhvich et al., 1989), and captive scalloped hammerhead sharks Sphyrna lewini (Crow et al., 1995). The pathogencity of $F$. solani to prawns and the histopathology of the infected animals have been widely studied by fish pathologists (Hatai and Egusa 1978; Chinain and Vey, 1988; Bian and Egusa, 1981; Momoyama, 1987). Morphology and some biological characteristics of $F$. solani isolated from prawns have been reported first by Hatai and Egusa (1978). In addition, $F$. solani is also known as an important plant pathogen that causes root and fruit rot in Cucurbita spp.,

\footnotetext{
* Corresponding author

E-mail: hatai@scan-net.ne.jp
}

sudden dead syndrome in soybean, and wilt in Ipomoea batana (O'Donnell, 2000).

$F$. solani was originally proposed as a major species in the section Martiella in the genus Fusarium (Wollenweber, 1913). Later the section included five species, ten varieties, and four forms (Wollenweber and Reinking, 1935). Snyder and Hansen (1941) combined three species ( $F$. solani, $F$. martti and $F$. coeruleum) into F. solani. This taxonomy, however, was not approved by Gerlach and Nirenberg (1982). Booth (1971) and Gerlarch and Nirenberg (1982), included four and six species in the section Martiella, respectively, from conidiogenesis and shapes of conidia which are major criterions for the classification. The main species, $F$. solani, in the genus Fusarium has been later reported in the literatures as formae specials (f. sp.), mating population (MP I - MP VII), or anamorph of Nectria haematococca due to its polytypic appearances (Matuo and Snyder, 1973). Because of its pathogenic importance, studies on the biological specification of $F$. solani species has also been developed (O'Donnell, 2000). Previous studies on the taxonomy of this complex fungal species have contributed valuable information on the limits of the specification and evolutionary relationships 
within the species, F. solani (Matuo and Snyder, 1973; VanEtten, 1978; Hawthorne et al., 1992; Suga et al., 2000; O'Donnell and Gray, 1995; O'Donnell, 2000). However, $F$. solani isolated from aquatic animals including crustaceans and fishes have never been studied in detail in previous reports.

This paper describes the pathogenicity to kuruma prawn, the morphology and phylogenetics of the strains isolated from kuruma prawns naturally infected with $F$. solani.

\section{Materials and Methods}

\section{Fungal isolation}

Kuruma prawns Penaeus japonicus (9 to $27 \mathrm{~g}$ in body weight) with Fusarium infection were obtained from different prawn farms in Kagoshima, Tokushima and Osaka Prefectures, Japan during 2000 to 2003 . Small pieces of the gills were taken from the diseased prawns and observed under a biological microscope to determine whether fungal elements of Fusarium were present. A small piece of the gills with Fusarium was washed in sterile seawater (SW), and inoculated onto potatoes dextrose agar (PDA: Nissui Co. Ltd., Tokyo, Japan). A small amount of ampicilin and streptomycin, then, were spread onto the agar medium to prevent bacterial contamination. A single spore culture to obtain a pure culture was made 4 days after incubation of the medium at $25^{\circ} \mathrm{C}$.

\section{Artificial infection}

Two fungal strains, NJM 0001 and NJM 0180 isolated from cultured kuruma prawns in Kagoshima Pref., Japan in 2000 and 2001, respectively, were used for an artificial infection. The experiments were done using kuruma prawns (average $3.2 \mathrm{~g}$ in body weight) at Fisheries Research Institute, Tokushima, Japan. Fungal strains were cultured on PDA at $25^{\circ} \mathrm{C}$ for 10 days. The fungal conidia were harvested in sterile SW, and the number of conidia was measured using a

Table 1. Fusarium solani isolated from Penaeus japonicus used in this study

\begin{tabular}{lrcc}
\hline NJM$^{*}$ & \multicolumn{1}{c}{ Date } & Prefecture in Japan & Farm \\
\hline 0001 &,- 2000 & Kagoshima & A \\
0178 & Dec 30, 2001 & Kagoshima & A \\
$0180^{* *}$ & Dec 30, 2001 & Kagoshima & A \\
0271 & Jan 25, 2002 & Tokushima & B \\
0272 & Jan 25, 2002 & Tokushima & B \\
0273 & Jan 25, 2002 & Tokushima & B \\
0377 & Feb 25, 2003 & Osaka & C \\
0378 & Feb 25, 2003 & Osaka & C \\
0379 & Feb 25, 2003 & Osaka & C \\
\hline
\end{tabular}

* Strain number of the Culture Collection in the Division of Fish Diseases (Nippon Veterinary and Animal Science University, Japan)

** Accession number: AY633744

Table 2. Comparative strains used for phylogenetic analysis*

\begin{tabular}{|c|c|c|c|c|}
\hline NRRL & Accession number & Anamorph & Teleomorph & $\begin{array}{c}\text { Mating population (MP) of } \\
\text { Nectria haematococca }\end{array}$ \\
\hline 22101 & AF178398 & Fusarium striatum & Nectria ipomoeae & \\
\hline 22142 & AF178411 & F. solanif. sp. cucurbitae & N. haematococca & v \\
\hline 22153 & $\mathrm{AF} 178410$ & F. solanif. sp. cucurbitae & N. haematococca & I \\
\hline 22157 & AF178421 & F. solanif. sp. mori & N. haematococca & III \\
\hline 22158 & AF178396 & Fusarium sp. & & \\
\hline 22161 & AF178395 & F. solani f. sp. robiniae & N. haematococca & VII \\
\hline 22163 & AF178394 & F. solanif. sp. xanthoxyli & N. haematococca & IV \\
\hline 22230 & $\mathrm{AF} 178420$ & F. solanif. sp. mori & N. haematococca & III \\
\hline 22275 & AY320140 & Fusarium sp. & & \\
\hline 22277 & AF178401 & F. solanif. sp. xanthoxyli & N. haematococca & IV \\
\hline 22316 & AF178423 & F. staphyleae & N. atrofusca & \\
\hline 22387 & AF178402 & Fusarium sp. & & \\
\hline 22389 & AF178404 & Fusarium sp. & Nectria sp. & \\
\hline 22395 & AF178405 & Fusarium sp. & & \\
\hline 22400 & AF178407 & F. solanif. sp. batatas & & \\
\hline 22402 & AF178408 & F. solanif. sp. batatas & & \\
\hline 22412 & $\mathrm{AF} 178414$ & Fusarium sp. & & \\
\hline 22436 & AY381138 & Fusarium sp. & Neocosmospora africana & \\
\hline 22570 & AF178422 & F. solani f. sp. piperis & & \\
\hline 22574 & AF178409 & Fusarium sp. & & \\
\hline 22586 & AF178416 & F. solanif. sp. robiniae & & \\
\hline 22823 & AY220215 & F. virguliforme & & \\
\hline 22825 & AY220216 & F. virguliforme & & \\
\hline
\end{tabular}

* Cited from O'Donnell (2000) and Aoki et al. (2003).

NRRL: Strain number of Agricultural Research Service Culture Collection (National Center for Agricultural Utilization Research, Peoria, Illinois, USA).

Strains shown as bold were used for comparison with conidial sizes of $F$. solani NJM 0180 . 
hemocytometer and adjusted to $5 \times 10^{5}$ conidia $/ \mathrm{mL}$. In the experiments, 30 prawns for each isolate were intramuscularly injected with the conidial suspension of 0.1 $\mathrm{mL}$. Prawns used in these experiments were maintained for 2 weeks in $100 \mathrm{~L}$ plastic tanks containing approximately $40 \mathrm{~L}$ of natural SW, 2 to $3 \mathrm{~cm}$ thick anthracite bottom bed, and running SW. Moribund and fresh dead prawns were sampled to observe clinical signs and fungal elements.

\section{Fungal morphology}

The fungal isolate, NJM 0180, was inoculated onto PDA and incubated at $25^{\circ} \mathrm{C}$ for 4 to 7 days in the dark. Morphology of fungal colony was recorded according to Kornerup and Wanscher (1978). Morphological characteristics of the isolate, which was inoculated onto SNA, after incubation on SNA $\left(\mathrm{KH}_{2} \mathrm{PO}_{4} 1 \mathrm{~g} / \mathrm{L}\right.$, $\mathrm{KNO}_{3} 1 \mathrm{~g} / \mathrm{L}, \mathrm{MgSO}_{4} .7 \mathrm{H}_{2} \mathrm{O} 0.5 \mathrm{~g} / \mathrm{L}, \mathrm{KCl} 0.5 \mathrm{~g} / \mathrm{L}$, glucose $0.2 \mathrm{~g} / \mathrm{L}$, saccharose $0.2 \mathrm{~g} / \mathrm{L}$, agar $23 \mathrm{~g}, 1 \mathrm{~N} \mathrm{NaOH} 0.6 \mathrm{~mL} /$ $\mathrm{L})$ at $25^{\circ} \mathrm{C}$ for $7-14$ days in the dark were illustrated using the Adobe Illustrator ${ }^{\mathrm{TM}}$ version 9.0 (Adobe System Co., San Jose, California, USA). Thirty conidia selected randomly from the isolate were measured in their size and calculated in their average dimensions and their associated standard deviations (SD). The comparative isolates were obtained from National Institute of Agro-Biological Science (NIAS), Tsukuba, Japan.

\section{Fungal molecular phylogeny}

The ribosomal DNA (rDNA) template was extracted from fungal mycelia of nine isolates by vigorously mixing a small portion of mycelia with a 50:25:24:1 solution of distilled water:phenol:chloroform:isoamyl alcohol. The mixture was centrifuged for five min at $13,000 \times g$. One microliter $(\mu \mathrm{L})$ of the supernatant was used as the template for polymerase chain reaction (PCR) along with a primer pair ITS5 and NL4 (White et al., 1990; O'Donnell, 1992). The cycling conditions for the PCR were modified from Suga et al. (2000) as follows: initial denaturation at $95^{\circ} \mathrm{C}$ for $15 \mathrm{~min}$; followed by 45 cycles of denaturation at $94^{\circ} \mathrm{C}$ for $20 \mathrm{~s}$, annealing at 55 to $56^{\circ} \mathrm{C}$ for one min, elongation at $72^{\circ} \mathrm{C}$ for $50 \mathrm{~s}$; and a final elongation at $72^{\circ} \mathrm{C}$ for ten min; and a $4^{\circ} \mathrm{C}$ soak. PCR products were purified and used for direct sequencing with six primers: ITS2, ITS3, ITS4, ITS5, NL1 and NL4 (White et al., 1990). DNA sequences from both strands were read on an ABI PRISM 377 DNA sequencing system (Applied Biosystems, Foster City, CA, USA).

Sequence data were aligned using Clustal $X$ programme version $1.8^{* 1}$ and the GeneDoc programme version $2.6^{* 2}$. Phylogenetic analyses were performed from sequences by the neighbour-joining (NJ) and the most-parsimonious (MP) methods using PAUP version

\footnotetext{
${ }^{* 1}$ http://www-igbmc.u-strasbg.fr/Biolnfo/ClustalX/Top.html

*2 http://www.psc.edu/biomed/genedoc/
}

4.0b8 (Sinauer Associates, Inc. Publishers, Sunderland, Massachusetts, USA). NJ trees were reconstructed with the HKY 85 model, and MP trees were reconstructed using the heuristic search option. Bootstrap values were evaluated for the best tree based on 1000 replicates. Fungi isolated from the infected prawns (Table 1) were sequenced, and sequence data for the other comparative strains (Table 2) were obtained by a BLAST search of GenBank*3.

\section{Results}

\section{Fungal isolation}

Black spots due to formation of melanotic pigment were observed in the gills of the diseased prawns (Fig. 1). Septate mycelia extending from the tip of the gill filaments and their conidia were clearly observed under a microscope (Fig. 2). The fungi were isolated from the gills in all collected samples by inoculating a small piece

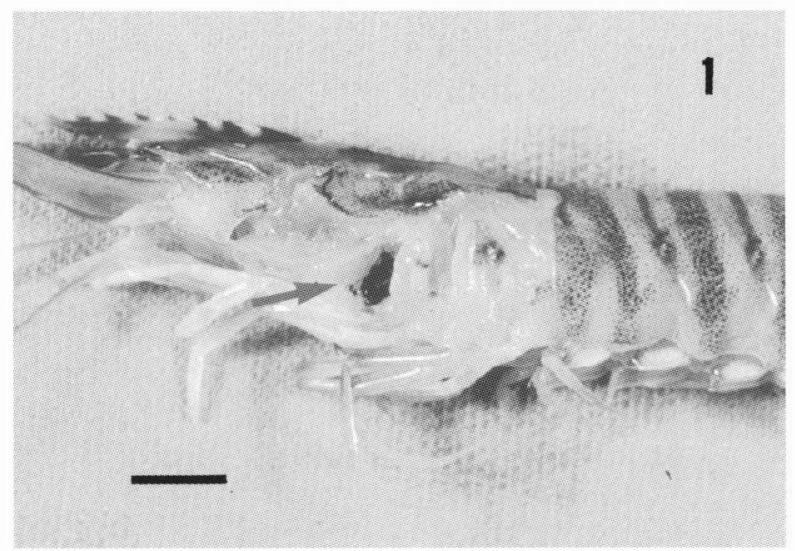

Fig. 1. A kuruma prawn Penaeus japonicus naturally infected with Fusarium solani showing melanization of the gill filaments (arrow). Scale bar $=2 \mathrm{~cm}$.

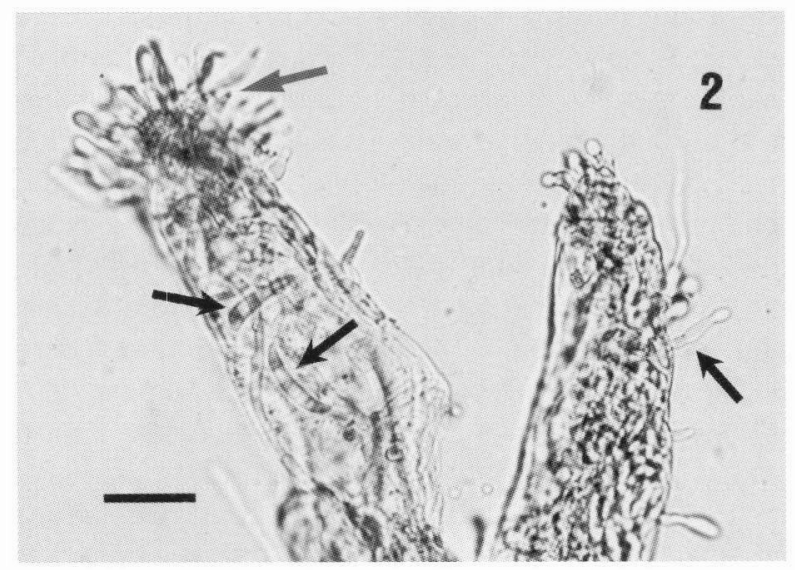

Fig. 2. Gills with fungal mycelia. Note: Fungus producing conidia in and on the gills (arrows). Scale bar $=30 \mu \mathrm{m}$.

\footnotetext{
*3 http://www.ncbi.nlm.nih.gov/BLAST/
} 
of gills onto PDA, and preliminary classified in the genus Fusarium. No fungi were isolated from the gills of five healthy prawns.

\section{Artificial infection}

Fungal hyphae and conidia were observed in the gills of moribund and freshly died prawns on 4 day after inoculation. The experimentally infected prawns showed similar black gills as compared with prawns naturally infected with the fungus. Accumulated mortalities after 2 weeks in the prawns inoculated with the isolates, NJM 0001 and NJM 0180 , were $80 \%$ and $67 \%$, respectively (Fig. 3). The injected fungus was re-isolated from the gill lesions using PDA. In contrast, 10\% prawns died in the control group, but no fungi were found in the prawns.

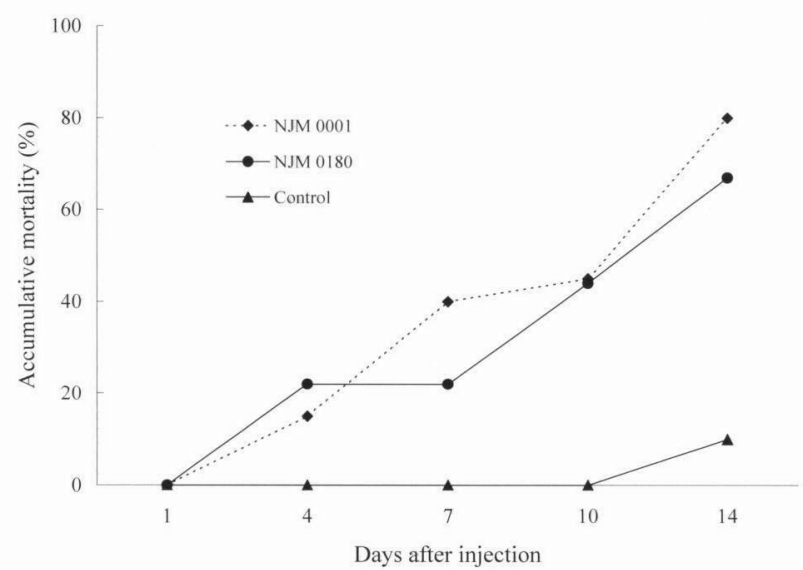

Fig. 3. Accumulative mortality of Penaeus japonicus caused by Fusarium solani intramuscularly injected with ca. 5 $\times 10^{4}$ conidia per prawn. Two strains of $F$. solani, NJM 0001 and NJM 0180, were used in the experiment.

\section{Fungal morphology}

Colony growth on PDA at $25^{\circ} \mathrm{C}$ in the dark was rapid with entire margin. On PDA, colony pigment on the reversed side of the plates was yellowish white to olive yellow or pale yellow, and turning brownish yellow in aged cultures. An odor was not perceptible from the cultures. Aerial conidiophores were long and unbranched or latterly branched, slightly narrow towards the apex, 37.5 to $85.0 \times 2.50$ to $3.25 \mu \mathrm{m}$, and lateral aerial conidiophores varied in length, and were usually long and branched. The aerial conidiophores bore mostly monophialidic conidiogenous cells, producing 0 to five-septate conidia; of which 0 to one-septate conidia (one to two-cell conidia) were abundant, and cohering in false head (Fig. 4a). These aerial conidia generally produced on the aerial mycelia at three to four day of post-inoculation on SNA, and they were predominantly oval, from ellipsoid to subcylindric. One-cell conidia on SNA in complete darkness were $9.89 \pm 2.03 \times 3.24 \pm$ $0.67 \mu \mathrm{m}$, and two-cells conidia on SNA in complete dark-

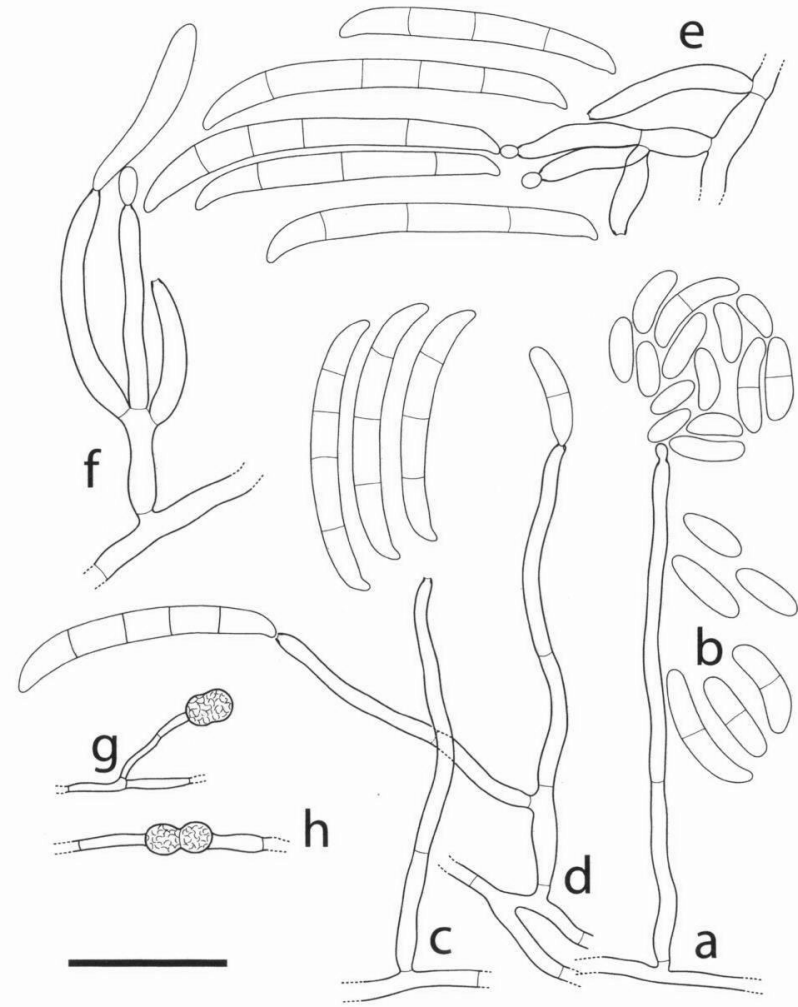

Fig. 4. Microscopic morphology of Fusarium solani NJM 0180 isolated from an infected Penaeus japonicus. Scale bar $=25 \mu \mathrm{m}$

a: Aerial conidiophore is long and unbranched, slightly narrow towards the apex, monophialidic, producing abundant 0 to one-septate conidia that cohere in a false head.

b: Oval or ellipsoid one-cell conidia and subcylindric or slightly curved two-cells conidia.

c: Unbranched aerial conidiophore bear three to fourseptate conidia and are slightly curved with a short and blunt apical cell and slightly notched basal cell.

d: A lateral branched aerial conidiophore producing one to four-septate conidia.

e: Irregularly and verticillately branched sporodochial conidiophores, bearing monophialides and producing three and four-septate conidia. Conidia extend from the basal part and curve to the apex. The dorsal side is more curved than ventral side, and there is a blunt apical cell and slightly notched basal cell.

f: A sporodochial conidiophore verticillately forming monophialides in the early stage of sporulation.

g: A terminal chlamydospore from conidiophore is smooth-walled, globose.

$\mathrm{h}$ : Intercalary chlamydospores in the hypha are smooth-walled, globose, and in a pair.

ness were $14.43 \pm 2.10 \times 3.60 \pm 0.56 \mu \mathrm{m}$ (Fig. 4b). The lateral aerial conidiophores contained two to five-septate conidia (Fig. 4c) and were subcylindric and regularly curved with a short and blunt apical cell, although they sometimes were slightly tapered towards the apex with very slightly notched basal cell (Fig. 4d). Three-septate conidia on SNA in complete darkness were $33.93 \pm 5.02$ 
$\times 4.39 \pm 0.43 \mu \mathrm{m}$, four-septate conidia on SNA in complete darkness were $40.95 \pm 3.43 \times 4.98 \pm 0.17 \mu \mathrm{m}$, and five-septate conidia on SNA in complete darkness were $45.68 \pm 3.78 \times 4.97 \pm 0.25 \mu \mathrm{m}$. Sporodochial conidiophores were irregularly or verticillately branched and bore monophialides mostly, producing three- to five-septate conidia, and rarely six- or seven-septate conidia (Fig. 4e and 4f). Sporodochial conidia were usually straighter and longer than those produced by aerial conidiophores, slightly curving from central dorsal area

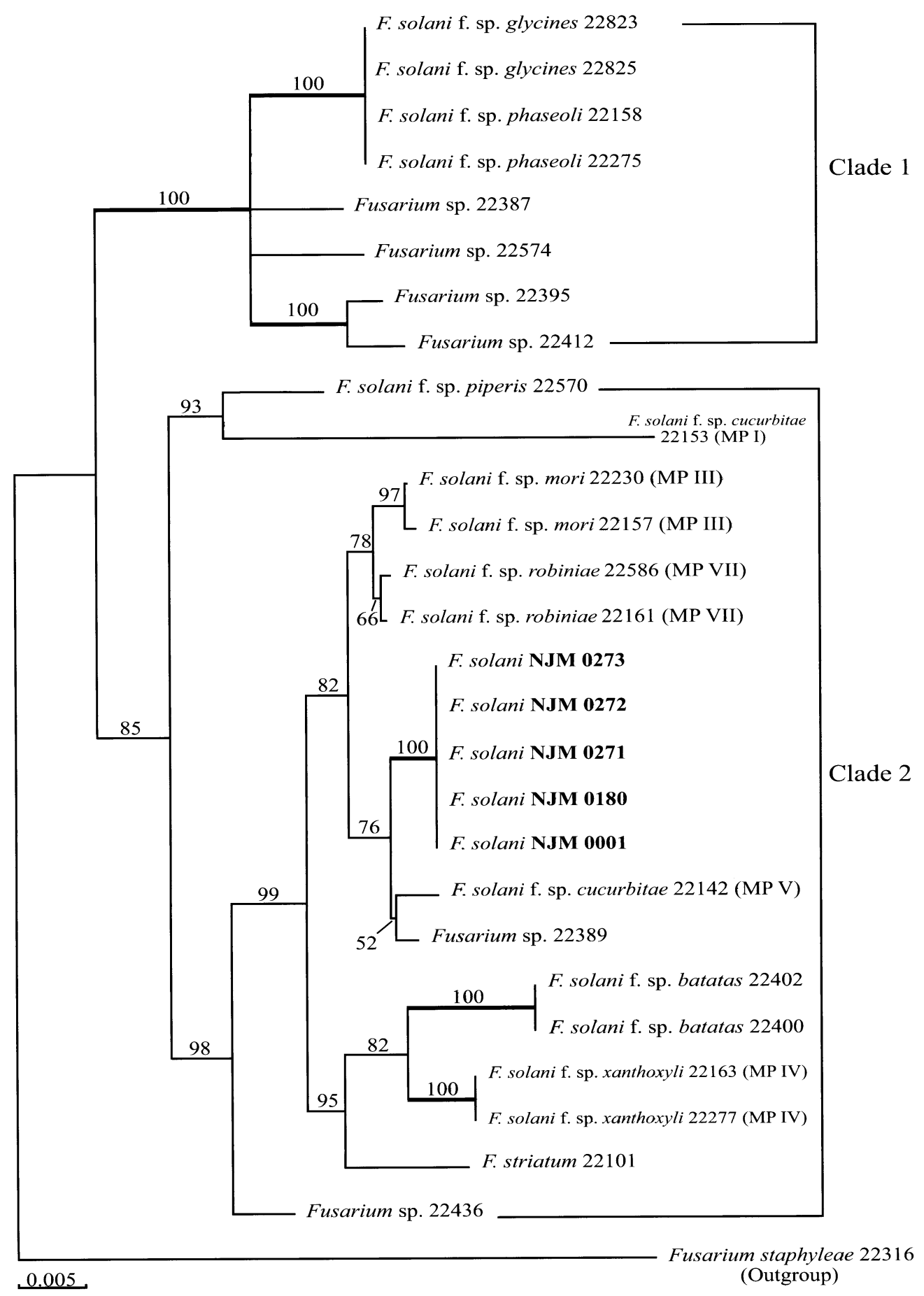

Fig. 5. A neighbour-joining tree based on the ITS rDNA including the complete sequences of 5.8S rDNA regions and a partial sequence of the $28 \mathrm{~S}$ rDNA from 27 of the in-group taxa within Fusarium solani complex. Note: The tree was rooted by an outgroup taxon Fusarium staphyleae NRRL 22316. All branches were supported with above 50\% bootstrap values from 1000 replicates. Branches with $100 \%$ bootstrap support are shown with bold lines. Five strains from prawns were indicated in bold letters. Scale bar represents proportional branch distances. 
toward the apex, with a blunt and sometimes pointed apical cell and indistinct notched basal cell (Fig. $4 \mathrm{e}$ and 4f). Chlamydospores were abundant, terminal or intercalary, smooth-walled, globose to subglobose, and occurred mostly in pairs. They were sometimes single and in short chains, 7.5 to $14 \mu \mathrm{m}$ in diameter, and greenish in color. A terminal chlamydospore from conidiophore (Fig. 4g) and an intercalary chlamydospore in the hyphae (Fig. 4h) were smooth-walled, globose, and in pair. The mass of sporodochial conidia was greenish. Three-septate conidia on SNA in complete darkness were $48.14 \pm 5.83 \times 4.08 \pm 0.38$, 4-septate conidia on SNA in complete darkness were $51.83 \pm 4.42 \times 4.29 \pm$ $0.35 \mu \mathrm{m}$, and five-septate conidia on SNA in complete darkness were $54.71 \pm 3.40 \times 4.66 \pm 0.32 \mu \mathrm{m}$. Based on the morphology as mentioned above, the isolate NJM 0180 was identified as Fusarium solani Martius 1842, which is also known as Fusisporium solani or Fusarium solani var. solani.

\section{Fungal molecular phylogeny}

Because the rDNA sequences of the nine isolates of $F$. solani randomly selected were identical, five strains (NJM 0001, NJM 0180, NJM 0271, NJM 0272 and NJM 0273) among the nine isolates were randomly chosen for the phylogenetic analysis. In this study, a phylogenetic analysis on a total 27 in-group taxa within $F$. solani complex was performed, in which $F$. staphyleae strain NRRL 22316 (teleomorph = Nectria atrofusca) was used to root the tree as described by O'Donnell (2000). The sequence data sets included DNA fragments, each of which contained 5.8S rDNA gene, a partial 28rDNA gene, ITS regions and was 1,127 base pair in length without the PCR-amplified primers.

The NJ tree (Fig. 5) shows two major clades (clade 1 and clade 2). All clusters of the NJ tree corresponded to one of the biological species, but $F$. solani f. sp. glycines (NRRL 22823 and NRRL 22825) and F. solani f. sp. phaseoli (NRRL 22158 and NRRL 22275) were clustered in one group with a $100 \%$ bootstrap value. The strains from the prawn used in this study were included in clade 2 with a high bootstrap support (85\%). Moreover, the strains were also clustered in a mono- phylogenetic group with sister group of MP $V$ (NRRL 22142) and the holothallic Fusarium sp. NRRL 22389. A high bootstrap value of $100 \%$ supported the grouping of the prawn strains. In addition, $F$. solani $f$. $s p$ piperis NRRL 22570 and $F$. solanif. sp. cucurbitae race 1 NRRL 22153 (MP I), and Fusarium sp. NRRL 22389 and $F$. solani f. sp. cucurbitae race 2 NRRL 22142 (MP V) were resolved in the two clusters with $93 \%$ and $52 \%$ bootstrap values, respectively.

\section{Discussion}

Morphology of the $F$. solani isolated from cultured kuruma prawns agreed well with systems provided by Booth (1971) and Gerlach and Nirenberg (1982). The species formed long aerial conidiophores and produced typical oval aerial conidia with one to two cells. And sporodochial conidiophores produced predominantly three-five-septate conidia that were slightly curved, short, and with a blunt apical and indistinctly pedicellate basal cell. These features are most distinguishing and diagnostic characteristics of the F. solani. Moreover, recent strains from prawns produced neither strong dark violet-blue pigment nor occasional polyphialides. The features differentiated them from $F$. solani var. coeruleum, which causes powdery rot of potatoes in storage (Booth, 1977).

Based on phylogenetic analysis, the $F$. solani isolated from prawns were cladistically sister of MP III, MP $\mathrm{V}$ and MP VII biological species. For this reason, conidial sizes of the prawn strain NJM 0180 were compared with four strains of the Nectria haematococca (Table 3). The sporodochial conidia of the strain NJM 0180 were longer and slightly more slender than the four strains of Nectria haematococca, biological species of the $F$. solani complex. Only the five-septate sporodochial conidia of strain NRRL 22157 (MP III) was similar to that of NJM 0180 . However, strains NRRL 22161 and NRRL 22586 (MP VII) showed the differences in the lengths of the sporodochial conidia. In addition, phylogenetic studies of phytopathogenetic fungus $F$. solani based on ITS rDNA have clearly showed that there was not a close association between

Table 3. Comparison of conidial sizes between Fusarium solani NJM 0180 and four strains of $F$. solani obtained from National Institute of Agro-Biological Science (NIAS)

\begin{tabular}{ccccccr}
\hline \multirow{2}{*}{$\begin{array}{c}\text { Conidia } \\
\text { formation }\end{array}$} & $\begin{array}{c}\text { Number } \\
\text { of cell }\end{array}$ & NJM 0180 & $\begin{array}{c}\text { NRRL 22142 } \\
\text { (MP V) }\end{array}$ & $\begin{array}{c}\text { NRRL 22157 } \\
\text { (MP III) }\end{array}$ & $\begin{array}{c}\text { NRRL 22161 } \\
\text { (MP VII) }\end{array}$ & $\begin{array}{c}\text { NRRL 22586 } \\
\text { (MPVII) }\end{array}$ \\
\hline Aerial & 1 & $10 \pm 2 \times 3.2 \pm 0.7^{*}$ & $8.7 \pm 1.6 \times 4 \pm 0.4$ & $9 \pm 2 \times 3.4 \pm 0.6$ & $9.2 \pm 2 \times 3 \pm 0.6$ & $9 \pm 2.2 \times 3.2 \pm 0.5$ \\
& 2 & $14.5 \pm 2 \times 3.6 \pm 0.6$ & $12.9 \pm 1.6 \times 4.5 \pm 0.4$ & $16 \pm 2 \times 4 \pm 0.4$ & $14.8 \pm 3 \times 4 \pm 0.5$ & $14 \pm 2 \times 4 \pm 0.4$ \\
Sporodochial & 4 & $48 \pm 6 \times 4 \pm 0.5$ & $41 \pm 3.5 \times 4.7 \pm 0.3$ & $38 \pm 3.5 \times 4.5 \pm 0.3$ & $41 \pm 4 \times 4.4 \pm 0.3$ & $34.3 \pm 6 \times 4.4 \pm 0.3$ \\
& 5 & $52 \pm 4.5 \times 4.5 \pm 0.3$ & $46 \pm 3 \times 5 \pm 0.2$ & $40 \pm 5.3 \times 4.5 \pm 0.3$ & $47 \pm 9 \times 4.7 \pm 1$ & $38 \pm 2.2 \times 4.7 \pm 0.3$ \\
& 6 & $55 \pm 3.4 \times 4.7 \pm 0.3$ & $49 \pm 4.5 \times 5 \pm 0.2$ & $55 \pm 6 \times 4.8 \pm 0.2$ & $50 \pm 3.3 \times 5 \pm 0.2$ & $42.3 \pm 3.1 \times 4.8 \pm 0.3$ \\
\hline
\end{tabular}

\footnotetext{
* average length \pm SD $\times$ average width \pm SD $(\mu \mathrm{m})$
} 
macroconidia types and phylogenetic relationships (Suga et al., 2000).

Overall, the phylogenetic analysis using both $\mathrm{NJ}$ and MP methods in this study strongly supported that the strains from prawns formed a part of a monophyletic group. Although, molecular phylogeny is strong tool for resolving the taxonomy among $F$. solani complex, more strains and different gene partitions of the F. solani isolated from prawn and the other aquatic sources should be studied to determine its precise phylogeny.

\section{Acknowledgement}

We are indebted with Dr. Takayuki Aoki of the National Institute for Agro-biological Science for his invaluable guides on the taxonomic treatments of the genus Fusarium and providing comparative strains of $F$. solani for the morphological comparisons.

\section{References}

Aoki, T., K. O'Donnell, Y. Homma and L. R. Alfredo (2003): Sudden-death syndrome of soybean is caused by two morphologically and phylogenetically distinct species within the Fusarium solani species complex $F$. virguliforme in North America and $F$. tucumaniae in South America. Mycologia, 95, 660-684.

Bian, B. Z. and S. Egusa (1981): Histopahology of black gill disease caused by Fusarium solani (Martius) infection in the kuruma prawn, Penaeus japonicus Bate. J. Fish Dis., 4, 195-201.

Booth, C. (1971): The genus Fusarium. Commonwealth Mycological Institute, Kew, Surrey, England, $237 \mathrm{p}$.

Booth, C. (1977): Fusarium: Laboratory guide to the identification of the major species. Commonwealth Mycological Institute, Kew, Surrey, England, $58 \mathrm{p}$.

Chinain, M. and A. Vey (1988): Experimental study of Fusarium solani: infections in Astacus leptodactylus and Pacifastacus leniusculus (Crustaceae, Decapoda). Dis. Aquat. Ani., 5, 215-223.

Crow, G. L., J. A. Brock and S. Kaiser (1995): Fusarium solani fungal infection of the lateral line canal system in captive scalloped hammerhead sharks, Sphyrna lewini, in Hawaii. J. Wildl. Dis., 31, 562-565.

Egusa, S. and T. Ueda (1972): A Fusarium sp. associated with black gill disease of the kuruma prawn, Penaeus japonicus Bate. Bull. Jap. Soc. Sci. Fisher., 38, 1253-1260.

Gerlach, W. and H. I. Nirenberg (1982): The genus Fusarium: A pictorial atlas. Mitt. Biol. Bundesanst. Land u. Forstwirtsch., 209, 155-161.

Hassan, S., A. Vey., P. Thuet and T. Jean-Paul (1999): Pathogenetic and toxic effects of Fusarium oxysporum (Schlecht) on survival and osmoregulatory capacity of Penaeus japonicus (Bate). Aquaculture, 178, 209-224.

Hatai, K. and S. Egusa (1978): Studies on the pathogenic fungus associated with black gill disease of kuruma prawn Penaeus japonicus II: Some of the note on the BGFusarium. Fish Pathol., 12, 225-231. (In Japanese, with English abstract.)

Hawthorne, B. T., J. Rees-George and P. G. Boradhurst (1992):
Mating behavior and pathogenicity of New Zealand isolates of Nectria haematococca (Fusarium solani). NZ. J. Crop Hort. Sci., 20, 51-57.

Hose, J. E., D. V. Lightner, R. M. Redman and D. A. Danald (1984): Observation on the pathogenesis of the imperfect fungus, Fusarium solani, in the California brown shrimp, Penaeus californiensis. J. Invertebr. Pathol., 44, 292303.

Iwamoto S., S. Tokumasu, Y. Suyama and M. Kakishima (2002): Molecular phylogeny of four selected species of the strictly anamorphic genus Thysanophora using nuclear ribosomal DNA sequences. Mycosience, 43, 160-180.

Kornerup, A. and J. H. Wanscher (1978): Methuen handbook of colour, 3 rd ed. Eyre Methuen, London. 252 p.

Lightner, D.V. and C. T. Fontain (1975): A mycosis of the American lobster Homarus americanus caused by Fusarium sp. J. Invertebr. Pathol., 25, 239-245.

Matuo, T. and W. C. Snyder (1973): Use of morphology and mating populations in the identification of formae specials in Fusarium solani. Phytopathology, 63, 562-565.

Momoyama, K. (1987): Distribution of the hyphae in kuruma shrimp Penaeus japonicus infected with Fusarium solani. Fish Pathol., 22, 15-23. (In Japanese, with English abstract.)

Muhvich, A.G., R. Reimschuessel, M. M. Lipsky and R. O. Bennett (1989): Fusarium solani isolated from newborn bonnethead sharks, Sphyrna tiburo (L.). J. Fish Dis., 12, 57-62.

O'Donnell, K. (1992): Ribosomal DNA internal transcribed spacers are highly divergent in the phytopathogenic ascomycete Fusarium sambucinum (Gibberella pulicaris). Curr. Genet., 22, 213-220.

O'Donnell, K. (2000): Molecular phylogeny of the Nectria haematococca - Fusarium solani species complex. Mycologia, 95, 919-938.

O'Donnell, K. and L. E. Gray (1995): Phylogenetic relationships of the soybean sudden death syndrome pathogen Fusarium solani f. sp. phaseoli from rDNA sequence data and PCR primer for its identification. Mycologia, 90, 465493.

Rhoobunjongde, W., K. Hatai, S. Wada and S. Kubota (1991): Fusarium moniliforme isolated from gills of kuruma prawn Penaeus japonicus with black gill disease. Nippon Suisan Gakkaishi, 57, 629-635.

Snyder W.C. and H.N. Hansen (1941): The species concept in Fusarium with reference to section Martiella. Am. J. Bot., 28, 738-742.

Suga, H., T. Hasegawa, H. Mitsui, K. Kageyama and M. Hyakumachi (2000): Phylogenetic analysis of the phytopathogenic fungus Fusarium solani based on the rDNA-ITS region. Mycol. Res., 104, 1175-1183.

VanEtten, H. D. (1978): Identification and additional habitats of Nectria haematococca mating population VI. Phytopathology, 68, 1552-1556.

White, T. J., T. Bruns, S. Lee and J. W. Taylor (1990): Amplification and direct sequencing of fungal ribosomal RNA genes for phylogenetics, In "PCR protocols" (ed. by M. A. Innis, D. H. Gellfand, J. J. Sninsky and T. J. White). Academic Press, New York, pp. 315-322.

Wollenweber, H. W. (1913): Studies on the Fusarium problem. Phytopathology, 3, 24-50.

Wollenweber, H. W. and O. A. Reinking (1935): Die Fusarien, ihre Beschreibung, Schadwirkung und Bekämpfung. Paul Pare, Berlin. 335 p. 